\title{
A New Model for Mentoring Graduate Students: Teach Them How to Teach
}

\section{Dr. Yunchen Huang, Mississippi State University}

Yunchen Huang just received his Ph.D. at Mississippi State University. His research focus is human factors engineering. He has engaged in both teaching and research related to human facotors in everyday life

Dr. Lesley Strawderman, Mississippi State University

Dr. John M. Usher P.E., Mississippi State University

Dr. John M. Usher is a professor and Department Head of Industrial Engineering at Mississippi State University. Dr. Usher's research interests focus on systems simulation, modeling, and analysis, as well as employing artificial intelligence in software environments to enhance system operation. He has published numerous papers in technical journals and conference proceedings, and continues to serve on the editorial staff for several journals. 


\title{
A New Model for Mentoring Graduate Students: Teach Them How to Teach
}

\begin{abstract}
Though graduate student mentoring has received a lot discussion in recent years, there is little discussion on the best way to train graduate students how to teach. A good mentoring system between professors and graduate students not only helps build a solid path through graduate students' careers, but is also pivotal to the success of engineering education. As more graduate students assume teaching responsibilities, it is important that they are given the advice and guidance regarding sound educational practices.
\end{abstract}

In this paper, a new teaching mentoring model used in an industrial engineering department is introduced. A brief comparison with graduate teaching preparation approaches in other industrial engineering departments, colleges, and universities is provided. Feedback from department administration, mentor \& mentee, and students of the mentee are discussed. Finally, summary results of the current mentoring program and suggestions for improvement for future mentoring programs are presented.

\section{Introduction}

A successful mentoring system is critical for a graduate student's success. Typical mentoring systems involve a senior professional who counsels, guides and tutor a mentee who's new into the profession ${ }^{1,2}$. Graduate student mentoring system is different from traditional academic advising system. In traditional advising, the major advisor instructs and teaches graduate student academic knowledge. However, a successful mentoring system will enable the mentee to learn regulations, unspoken rules, and knowledge of how to cope with unexpected situations. Simply put, mentoring system teaches graduate students "how to" instead of "what", and provide opportunities for them to practice before going into their professional career.

The educational goal for graduate students is to cultivate them to be successful in acquiring academic knowledge, be independent on research, creative in generating research idea and excel in teaching. While there are a lot of papers addressing graduate students mentoring relationship to improve their academic competency and research ability ${ }^{3,4}$, there are few, if any, research papers focusing on the graduate student mentoring models that promote a student's teaching ability. Individuals who are preparing for careers in elementary or secondary education are required to complete a set of courses and supervised teaching practice to demonstrate their teaching skills. But our doctoral students seldom receive the opportunity to systematically learn or practice their teaching roles. Ironically, teaching proficiency is one of the most important attributes for a new professor to be successful in academia. As more graduate students assume teaching responsibilities, it is important that they are given the advice and guidance regarding sound educational practices. As the educator for the next generation of engineers, we have to take the responsibility to make sure that not only do we provide excellent education to our students, but we also provide guidance and help for the next generation of educators.

Wankat and Oreovicz ${ }^{5}$ conducted a survey to assess students' perspectives regarding a specific course that aimed at teaching engineering graduate students how to teach. They found that the 
course was considered helpful for academic careers. They also suggested an instructional team be formed with experienced engineering faculty teaching the course. While specific courses are critical in conveying key skill sets to teach, the lack of hand-on practice of teaching and real-time feedback from faculty members or students remained a drawback of this approach.

Instructional programs that teach universities' teaching assistants has also received a lot of research $^{6-8}$. Shannon et al. ${ }^{7}$ did a study of universities' teaching assistants and found that previous teaching experience and feedback are important to the teaching outcome of graduate teaching assistant. But unguided experience usually leads to the same or less effective behaviors as a result of poor or nonexistent supervision. They also called for an improved training program to be implemented for graduate teaching assistants.

With the same objective, the Preparing Future Faculty (PFF) program has been implemented in many universities. It is found to provide students with little or no teaching experience a chance to gain that type of experience and to decide if teaching was their desired career path ${ }^{9,10}$. In addition, the PFF program allows graduate students who have teaching duties to discuss any problems they may be having, exchange new teaching skills or tools and to learn to do their teaching jobs better ${ }^{9}$.

As a more specific and hands-on approach to teach graduate students how to teach, faculty mentoring comes into existence in many academic programs. Sherwood et al. ${ }^{11}$ examined a mentoring program in a Chemical Engineering department and presented the perspective from mentee, mentor and students regarding the motivation to teach, course preparation, lecture delivery and additional assistance. They found the mentoring program was beneficial for the mentee to improve the ability in organizing cohesive lectures, constructing exams and assignments, as well as improving presentation skills. They also found the mentoring system can help the mentor to improve their own teaching by assessing the students and sharing the enthusiasm and energy of younger instructors.

In this paper, a teaching mentoring model used in an industrial engineering department is introduced. A brief comparison to graduate teaching preparation approaches in other industrial engineering departments, colleges, and universities is provided. Feedback from department administration, mentor \& mentee, and students of the mentee will be discussed. Finally, summary results of the current mentoring program and suggestions for improvement for future mentoring programs will be presented.

\section{Model for Mentoring Graduate Student}

The graduate student teaching mentoring program was started during the spring 2012 in the Department of Industrial and Systems Engineering at Mississippi State University. The objective of this specific mentoring program is to teach the graduate student how to be in charge of an entire course by him/herself.

The course that was taught by the graduate student mentee was Engineering Statistics I. This course is required for all industrial engineering undergraduates, and is also taken by many other engineering majors. Students in the course are primarily juniors and seniors. The course was 
divided into two sections. Section one, led by the faculty member (also the mentor in the mentoring program), had 65 students enrolled. Section two, led by the graduate student (the mentee in the mentoring program), had 35 students enrolled. To keep the course consistent, both sections of the course used the same class material and kept the same structure and schedule.

The faculty member, who is the mentor in this mentoring program, has more than nine years teaching experience in engineering education and six years teaching experience in the department. The graduate student, who is the mentee in this mentoring program, was a fifth year PhD student in Industrial Engineering, and was a tier three certified teaching assistant in the university (certified to teach an entire course).

The mentor and mentee were each in charge of their own section of course. However, they met every week to discuss course material (class notes, quizzes, in-class activities, homework, exams, etc.), course progress, students’ performance (in-class climate, students' questions) and teaching tips and skills.

\section{Comparison with Approaches of Mentoring in Current Programs}

Comparison of current teaching mentoring practices and our mentoring model is provided in Table 1. Many universities provide TA workshops for graduate students to learn basic teaching techniques. This provides an opportunity for graduate students to learn how to teach and the TA workshop help to cultivate their teaching philosophy. However, little hands-on opportunity is given to let graduate students practice what they learn from the workshop. Many preparing future faculty programs (PFF) share the same limitation. While PFF focuses on developing doctoral student's teaching philosophy and prepare them for a teaching career in academia, few in-class experiences are available for the trainees.

This limitation of missing on practical teaching experience is addressed by assigning graduate students in a lab TA or an instructor of a course. But with limited knowledge of how to teach, new teachers usually face a slow learning curve when let loose in teaching their own course. The quality of the lecture is also undermined in this situation. Lab TAs will receive more feedback from the professor. But the focus will be mainly on the lab content. No systematical mentorship and devotion of time is provided specifically to improve graduate students' teaching.

The faculty mentoring program discussed by Sherwood et al. ${ }^{11}$ allows the PhD students to learn the teaching skills while having practical teaching experience under the mentor of a faculty member. Our mentoring program differs with them in that we construct two separate sections of the course to be taught both by the faculty member and the PhD student. This allows the faculty member to understand the teaching requirement and key points in the content. Faculty member can also discuss the content and teaching experience with the PhD student and achieve mutual learning. 
Table 1. Comparison of Current Teaching Mentoring Approach and Our Mentoring Model

\begin{tabular}{lcccccc}
\hline & $\begin{array}{c}\text { Teaching } \\
\text { Skills }\end{array}$ & $\begin{array}{c}\text { Teaching } \\
\text { Philosophy }\end{array}$ & $\begin{array}{c}\text { Practical } \\
\text { Experience }\end{array}$ & $\begin{array}{c}\text { Mentor } \\
\text { Feedback }\end{array}$ & $\begin{array}{c}\text { Mutual } \\
\text { Learning }\end{array}$ & $\begin{array}{c}\text { Example } \\
\text { Literature }\end{array}$ \\
\hline TA workshop & $\mathrm{X}$ & $\mathrm{X}$ & & & & {$[12]$} \\
Lab TA & & & $\mathrm{X}$ & & & {$[13]$} \\
$\begin{array}{l}\text { TA as an } \\
\text { Instructor }\end{array}$ & & & $\mathrm{X}$ & & & {$[7,13]$} \\
$\begin{array}{l}\text { Preparing for } \\
\text { Future Faculty }\end{array}$ & $\mathrm{X}$ & $\mathrm{X}$ & & & & {$[9,10]$} \\
Faculty & $\mathrm{X}$ & $\mathrm{X}$ & $\mathrm{X}$ & $\mathrm{X}$ & & {$[11]$} \\
Mentoring & $\mathrm{X}$ & $\mathrm{X}$ & $\mathrm{X}$ & $\mathrm{X}$ & $\mathrm{X}$ & $\mathrm{N} / \mathrm{A}$ \\
Our Model & $\mathrm{X}$ & & & & \\
\hline
\end{tabular}

\section{Results \\ Feedback from administrative level}

From the perspective of administrative level, it seems that many academic programs work at preparing doctoral students to be research scholars in their future academic positions. This is an important goal, but of equal importance is the need to produce academicians that have received pedagogical training that adequately prepares them to teach the next generation of engineers. Teaching is not something that comes naturally to most persons and there is no reason that doctoral engineering programs cannot also provide opportunities for such training. Therefore, it has become engineering educators' goal to provide such training for academic bound doctoral students.

To provide adequate training requires faculty committed to the goal that are willing to provide the time and energy to disciple the students in the art of teaching. In addition, the department head must be willing to dedicate financial resources to support the student in the classroom. There is always some risk when placing a new instructor in the classroom for the first time whether they are a new faculty, adjunct, or graduate student. The administrator's concern is that the students receive effective instruction afforded them. Use of an assigned mentor with a dedicated interest in the student reduces this risk and provides a strong support system that increases their chance of success.

It is important that the administrative level also take part in the process. This begins with an initial interview of the student to ensure they understand the importance of the assignment and all that will be required of them during the semester. Then it is beneficial to take the time to sit-in on one or two lectures during the semester (preferably about midway and near the end of the semester). These experiences help build the administrator's confidence in the skills of the graduate student, indicate if adjustments need to be made in the mentoring relationship, and provide a second source of feedback for the student that can be shared through subsequent meetings one-on-one with the student. This direct exposure to the graduate student's teaching experience will also help provide details that the administrator can use when writing future recommendations. 
Given the current experience with this mentoring system and other approaches that have been used in the past, this approach has provided the best experience for the graduate student in terms of effectively imparting a full range of training while reducing the risk to the students in the class. There is no replacement for experiential training particularly in the field of teaching.

\section{Feedback from mentor}

Faculty members are deeply invested in the quality of education for undergraduates, as well as the academic training of graduate students. As PhD students prepare for careers in academia, it is essential that they be exposed to all aspects of life as a professor: grant writing, publishing, and teaching are just a few of those areas.

This mentoring program was a useful and effective system for the faculty mentor. The mentor was teaching a different section of the same class, so mentoring time frequently overlapped with course preparation time. Decisions about the course were made as a team, allowing the mentee to understand the mentor's process at the beginning of the course. Later in the semester, the mentee was able to take more of a leadership role in course planning.

This system allowed the mentor to ensure quality instruction without devoting an overwhelming amount of time to supervision. The team based approach to course preparation was advantageous to the mentor, and also helped the mentee prepare for a career in academia. As problems arose in the course (as they do in each course), the mentee was able to easily communicate with the mentor since they were both teaching the same material.

\section{Feedback from mentee}

PhD students who are looking forward to a career in academia are always eager to gain hands-on teaching experience during graduate study. The majority of graduate programs only provide theoretical knowledge of how to teach for their graduate teaching assistants. This type of experience is great. But nothing is equally helpful as the hands-on experience of teaching an entire section of the course. What's more beneficial and influential to a $\mathrm{PhD}$ student is the selfimpression and confidence as a scholar and an educator in his/her field.

Through the mentoring program the PhD student learned how to deliver a professional, informative, interactive, while also interesting lecture. In addition, the PhD student was able to learn how to interact with students as well as how to engage student and make the course flexible instead of following a rigid teaching/learning format. In addition, the PhD student also had the opportunity to take leadership in developing meaningful course materials such as lecture notes, quizzes, exams, assignment, etc.

During this mentoring system, the $\mathrm{PhD}$ student did encounter difficulties such as language issues (as an international student), communication issues and time management issues. But the faculty mentor played a key role in helping to address these issues and teach the $\mathrm{PhD}$ student what the mentor will do in a specific classroom teaching scenarios. The mentor served as a great reference of what the mentee will do in classroom. The PhD student believed that the mentoring program was rewarding and helpful for his/her career in academia. This mentoring program can be 
improved by providing more feedback from students, mentor, enrich the class type and incorporate peer discussion between graduate student mentees.

\section{Feedback from student level}

Two class climate surveys were provided to students, one at mid-semester and one at the end of the semester. The results of mid-semester survey are provided in Table 2. In addition, students' comments showed they are in favor of the active teaching style and in-class activity conducted by the mentee instructor.

Table 2. Mid-term Survey Results of Teaching Effectiveness

\begin{tabular}{lc}
\hline Survey Questions & $\begin{array}{c}\text { Percentage of Positive } \\
\text { Response (N=25) }\end{array}$ \\
\hline $\begin{array}{l}\text { Are you able to view the lecture presentations adequately? } \\
\text { Are you able to contact and communicate with the instructor in a } \\
\text { timely and efficient manner? }\end{array}$ & $80 \%$ \\
$\begin{array}{l}\text { Do the lectures provide enough detail? Are they interesting? Do } \\
\text { they keep you connected or are you drifting away? }\end{array}$ & $84 \%$ \\
$\begin{array}{l}\text { Do you understand what the instructor expects from you in this } \\
\text { course? Do you feel it's reasonable? }\end{array}$ & $68 \%$ \\
\hline
\end{tabular}

For the teaching evaluation survey at the end of the semester, the average score for the mentee instructor is 3.9 (out of 5). Students thought that he is a "good teacher" and it was "a great class". However there are also suggestions such as "add more interactive exercise in class" and "wisdom comes with time.”

\section{Discussion and Conclusion}

Our mentoring model would be most appropriate for doctoral students who are aiming for a career in academia. Support from the administrative level and help from an experienced professor is essential to make the mentoring system work. Based on our experience and results, the graduate student mentoring model has several advantages. First, $\mathrm{PhD}$ students will get independent instructor experience which could prepare them for the academic job market. This experience is also valuable for them to form their own teaching philosophy and pedagogy. Second, the pairing of advisor and advisee reduced the time commitment for the mentor as he/she is more acquainted with the mentee. In addition, the faculty mentor can provide very detailed advice and feedback based on the existing relationship. Third, the faculty mentor and PhD student teach the same course in the same semester. In this case, they used the same materials (lecture slides, homework assignments, exams) for both sections. They would take turns creating them, and then provide feedback to one another. In this way PhD student can get regular feedback on course materials developed. And since they are teaching the same material, the $\mathrm{PhD}$ student can come to professor with questions that are easily addressed. PhD students can also discuss pedagogy and student learning with the faculty mentor immediately after class. At last, this mentoring/supervision system not only teaches $\mathrm{PhD}$ students how to teach, but also increases the instruction quality for the students in classroom. 
To achieve an effective mentoring outcome, the selection of an appropriate mentor is critical. In this case, the mentor is experienced in teaching enthusiastic in developing teaching skills. The mentor is also experienced in the specific course that was taught. More importantly, the mentor is also the major advisor of the mentee, which not only enhanced the mentoring relationship between mentor and mentee, but also facilitated the communication and learning for the mentee.

This mentoring model does have some disadvantages. For example, since the two sections of class is held at the same time, there is no practical way for the faculty mentor to observe mentee's teaching and provide real-time feedback. In addition, students in the two sections compare the class, and often are disgruntled when things differ, which is also a standard problem when courses have multiple sections, not unique to this program. Finally, it does require extra resources from the department to offer two distinct sections of a course, compared to one large section.

Based on the results, potential improvement is provided but not limited to the following. A better feedback system needs to be implemented. The mentor should be able to attend the mentee's class and provide feedback after. While feedback from students is critical, students often refrain from offering suggestions. This can be complemented by the suggestions from the mentor. The mentor should be able to spot any weaknesses in teaching and communicate them to the mentee. To help PhD students create their own teaching style, it is also beneficial to allow the mentee to observe their mentor (or distinguished instructors) teach a course. They could discuss teaching techniques and skills after class, which would help the mentee cultivate his or her teaching philosophy. The PhD student should be required to write a teaching philosophy before and after the mentoring experience.

\section{References}

1. Dreher, G. P., \& Ash, R. A. (1990).A comparative study of mentoring among men and women in managerial, professional, and technical positions. Journal of Applied Psychology, 75, 539-546.

2. Gerstein, M. (1985). Mentoring: An age old practice in a knowledge-based society. Journal of Counseling and Development, 64 (2), 156-157

3. Council of Graduate Schools. (1990). Research student and supervisor: An approach to good supervisory practice. Washington, DC: Author.

4. Hesli, V., Fink, E., \&Duffy, D. (2003). Mentoring in a positive graduate student experience: Survey results from the Midwest region, Part I. PS: Political Science and Politics, 36(3), 457-460.

5. Wankat, P. C. \& Oreovicz, F. S. (2005). Teaching prospective engineering faculty how to teach. International Journal of Engineering Education, 21 (5), 925-930

6. Torvi, D. A. (1994). Engineering graduate teaching assistant instructional programs: training tomorrow's faculty members, Journal of Engineering Education, 2-5.

7. Shannon, D. M., Twale, D. J. \& Moore, M. S. (1998). TA teaching effectiveness: The impact of training and teaching experience. The Journal of Higher Education, 69, 440-466.

8. DeChenne, S.E. (2010). Learning to teach effectively: Science, technology, engineering, and mathematics’ graduate teaching assistants’ teaching self efficacy. Unpublished dissertation. Corvalis, OR: Oregon State University.

9. Lewandowski, G., \& Purdy, C. (2001). Training future professors: the preparing future faculty (PFF) program in electrical and computer engineering and computer science at the University of Cincinnati, Proceedings 2001 ASEE Conference, Albuquerque, NM. 
10. Austin, A. E. (2002). Creating a bridge to the future: Preparing new faculty to face changing expectations in a shifting context. Review of Higher Education, 26(2), 119-144.

11. Sherwood, J. L., Peterson, J. N. \& Grandzielwski, J. M. (1997). Faculty mentoring: a unique approach to training graduate students how to teach. Journal of Engineering Education,86, 119-123.

12. Johnson, P.E. (2001). Changing roles for the Teaching Assistant: a workshop plan. Journal of Graduate Teaching Assistant Development, 8(1), 33-35

13. Park, C. (2004). The graduate teaching assistant (GTA): lessons from North American experience. Teaching in Higher Education, 9(3), 349-361. 